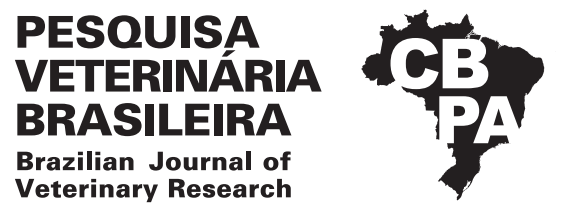

Pesq. Vet. Bras. 39(6):382-387, June 2019 DOI: $10.1590 / 1678-5150-P V B-6229$

Original Article

ISSN 0100-736X (Print)

ISSN 1678-5150 (Online)

\title{
Obstructive urolithiasis in growing-finishing pigs ${ }^{1}$
}

\author{
Marina P. Lorenzett ${ }^{2}$ (D), Raquel A.S. Cruz ${ }^{2}$ (D), Bianca S. Cecco², Claiton I. Schwertz², \\ Márcia E. Hammerschmitt ${ }^{2}$, Daniela T. Schu ${ }^{3}$, David Driemeier ${ }^{2}$ \\ and Saulo P. Pavarini ${ }^{2 *}$ (iD)
}

\begin{abstract}
Lorenzett M.P., Cruz R.A.S., Cecco B.S., Schwertz C.I., Hammerschmitt M.E., Schu D.T., Driemeier D. \& Pavarini S.P. 2019. Obstructive urolithiasis in growing-finishing pigs. Pesquisa Veterinária Brasileira 39(6):382-387. Setor de Patologia Veterinária, Departamento de Patologia Clínica Veterinária, Faculdade de Veterinária, Universidade Federal do Rio Grande do Sul, Av. Bento Gonçalves 9090, Prédio 42505, Porto Alegre, RS 91540-000, Brazil. E-mail: sauloppvet@yahoo.com.br

Obstructive urolithiasis is a disease characterized by the presence of uroliths in the urinary tract, with consequent obstruction of excretion pathways. This paper described the epidemiological and clinical-pathological findings of 22 outbreaks of urolithiasis in growing-finishing pigs in Southern Brazil. All affected pigs were male and clinical presentation consisted of lethargy, dysuria, rectal prolapse, abdominal distention, peripheral cyanosis and reluctance to move. Clinical progression course ranged from 12 hours to one week, and the lethality rate was $100 \%$. Gross changes were characterized by urinary bladder rupture associated with marked amount of yellowish liquid with ammoniacal odor (urine) in the abdominal cavity (uroperitoneum), as well as mild fibrin deposition on the surface of abdominal organs and hydronephrosis. Urinary uroliths ranging from 0.3 to $1 \mathrm{~cm}$ in diameter were often observed obstructing the lumen of the penile urethra and sometimes those were free in the abdominal cavity. Histopathological findings included diffuse and marked urinary bladder edema and hemorrhage associated with inflammatory infiltrate of lymphocytes, plasma cells, and macrophages. Diffuse and marked necrosis of the mucosal epithelium was observed in the penile urethra. Intense fibrin deposition and inflammatory infiltrate of neutrophils were noted in the peritoneum, as well as in the serosa of the organs in the abdominal cavity. Uroliths were submitted to the method of qualitative determination of the mineral components, and were compatible with calcium carbonate and magnesium ammonium phosphate. Growing pigs ration analysis revealed low levels of calcium in relation to phosphorus, resulting in a Ca:P ratio of approximately $0.35: 1$. Histological findings and mineral analysis suggest that outbreaks of urolithiasis were related to a nutritional imbalance in the proportions of dietary calcium and phosphorus. The main cause of mortality was related to dehydration and uroperitoneum.
\end{abstract}

INDEX TERMS: Swine, urinary system, uroliths, uroperitoneum, mineral imbalance, calcium, phosphorus.

RESUMO.- [Urolitíase obstrutiva em suínos de crescimento e terminação.] Urolitíase obstrutiva é uma enfermidade caracterizada pela presença de urólitos no trato urinário,

\footnotetext{
${ }^{1}$ Received on December 13, 2018.

Accepted for publication on January 31, 2019.

${ }^{2}$ Setor de Patologia Veterinária, Departamento de Patologia Clínica Veterinária, Faculdade de Veterinária, Universidade Federal do Rio Grande do Sul (UFRGS), Av. Bento Gonçalves 9090, Prédio 42505, Porto Alegre, RS 91540-000, Brazil. *Corresponding author: sauloppvet@yahoo.com.br

${ }^{3}$ Médica Veterinária, Cooperativa Ouro do Sul, Rua 25 de julho 112, Centro de Harmonia, RS 95785-000, Brazil.
}

com consequente obstrução das vias de excreção. Este artigo descreve os achados epidemiológicos e clínico-patológicos de 22 surtos de urolitíase em suínos de crescimento e terminação no Sul do Brasil. Os suínos afetados eram machos e clinicamente apresentavam letargia, disúria, prolapso retal, abaulamento do abdômen, extremidades cianóticas e relutância em movimentar-se. A duração dos sinais clínicos variou de 12 horas a uma semana, e a letalidade foi de $100 \%$. As alterações macroscópicas caracterizaram-se por ruptura da bexiga com acentuada quantidade de líquido de coloração amarelada e odor amoniacal (urina) livre na cavidade abdominal 
(uroperitônio), além de discreta deposição de fibrina sobre os órgãos e hidronefrose. Frequentemente obstruindo o lúmen da uretra peniana e por vezes livre na cavidade abdominal, era possível observar urólitos urinários que variavam de 0,3 a $1 \mathrm{~cm}$ de diâmetro. Os achados histopatológicos incluíram edema e hemorragia difusos e acentuados na bexiga, associado a infiltrado inflamatório predominante de linfócitos, plasmócitos e macrófagos. Na uretra peniana havia necrose difusa e acentuada do epitélio da mucosa. No peritônio e nas serosas dos órgãos da cavidade abdominal havia intensa deposição de fibrina e infiltrado neutrofílico. Os urólitos foram submetidos ao método de determinação qualitativa dos componentes minerais, os quais foram compatíveis com carbonato de cálcio e fosfato de amônio magnesiano. A análise da ração de crescimento revelou baixos níveis de cálcio, em relação ao fósforo, perfazendo uma relação Ca:P de aproximadamente 0,35:1. Os achados histológicos e as dosagens minerais sugerem que os surtos de urolitíase foram relacionados a um desequilíbrio nutricional nas proporções de cálcio e fósforo dietético. A principal causa da morte dos suínos foi relacionada à desidratação e ao uroperitônio.

TERMOS DE INDEXAÇÃO: suíno, sistema urinário, urólitos, uroperitônio, desbalanço mineral, cálcio, fósforo.

\section{INTRODUCTION}

Obstructive urolithiasis is a disease characterized by the presence of uroliths in the urinary tract, with consequent obstruction of excretion pathways (Radostits et al. 2000, Cianciolo \& Mohr 2016). Uroliths or calculi are macroscopic mineral concretions, which are composed by precipitated urinary solutes, associated with small amounts of organic matter (Drolet 2012, Cianciolo \& Mohr 2016). Urolithiasis affects similarly males and females; however, urinary obstruction is a condition exclusively reported in males, mainly in castrated hogs (Radostits et al. 2000).

Case descriptions of urolithiasis affecting pigs are scarce when compared with other domestic species (Drolet 2012). Nevertheless, similarly to other species, males are more frequently affected due to specific features regarding their urinary tract morphologic anatomy (Maes et al. 2004). The condition is sporadically detected in pigs of all age groups and is occasionally observed as an incidental finding in pigs at the slaughter. Urinary calculi found in pigs may present various compositions, including calcium carbonate, calcium apatite, magnesium ammonium phosphate, uric acid, and urate (Drolet 2012).

Urinary calculi formation frequently results from the interaction of physiologic and nutritional factors with husbandry practices (Loretti et al. 2003), and is mainly related to the excessive or imbalanced ingestion of minerals present in the drinking water and feed (McIntosh 1978, Larson 1996, Radostits et al. 2000, Drolet 2012). Imbalance in the calcium and phosphorus ratio leads to high excretion of urinary phosphate, which is an important factor in the formation of phosphate calculi. Diets presenting high mineral concentration, associated with high levels of mucoproteins in the urine of fast growing animals, are likely the most important factor for calculogenesis (Radostits et al. 2000). Urinary $\mathrm{pH}$, reduced water intake, urinary stasis, treatment with certain drugs, and preexisting urinary tract disease are also factors associated with the occurrence of urolithiasis. Such predisposing factors may act synergistically for calculi formation or play a role individually (Drolet 2012, Sobestiansky 2012). In the present study, the epidemiological and clinical-pathological findings of outbreaks of urolithiasis in growing-finishing pigs in Southern Brazil are reported.

\section{MATERIALS AND METHODS}

Clinical and epidemiological data were obtained directly with the farm owner and the referring field veterinarian. Out of forty finishing male pigs showing clinical signs of lethargy and dysuria submitted for necropsy during the outbreaks, four animals underwent histopathological examination. During the necropsy procedures, samples of various organs were collected for histological examination, fixed in $10 \%$ formalin, routinely processed and stained by hematoxylin and eosin (HE). In one pig submitted for necropsy, serum samples were collected in order to obtain total serum calcium and phosphorus values. Ration samples (ration for growing pigs, phases 1 and 2) were collected to determine the levels of calcium, phosphorus, magnesium, fluoride, sodium and moisture. In addition, a group of pigs with history of urolithiasis was monitored at the slaughterhouse. In this occasion, 20 urinary bladders were collected and urine samples were obtained for urinalysis. Uroliths collected during the necropsy procedures were tested using the qualitative determination technique for regular components of renal calculus (kit Cálculo Renal Bioclin ${ }^{\circledR}$, Quibasa Química Básica Ltda, Belo Horizonte/MG, Brasil).

\section{RESULTS}

From April 2016 to September 2017, 22 growing-finishing pig farms integrated to the same company in the municipality of Harmonia, Rio Grande do Sul State, Brazil, reported the occurrence of obstructive urolithiasis in pigs ranging from 73 to 163 days of age. During the outbreaks, 44 pigs from 22 different growing-finishing sites died. Groups of pigs ranged from 400 to 600 hogs, with an average of 500 pigs allocated in the same farm. During the outbreaks, these pigs, originally from 3 farrowing farms, were fed the same ration. Feed and water access ad libitum were provided. The types of drinking systems varied from farm to farm, and were represented by drinking bowl (16/22), drinking bowl with nipple (4/22) and nipple drinkers $(2 / 22)$.

All affected pigs were male, and the clinical manifestation included lethargy and dysuria, which was characterized by vigorous abdominal movements showing an attempt to urinate, causing marked rectal prolapse (Fig.1A), and progressing to distended abdomen (Fig.1B), peripheral cyanosis (distal extremities), and reluctance to move. Clinical signs were observed in pigs ranging from 15 days after allocation in the growing-finishing facilities until the animals reached age for slaughter. Clinical progression lasted from 12 hours to one week. Disease morbidity varied from 0.2 to $1 \%$ among different pig herds (average $0.6 \%$ ), and lethality rate was $100 \%$.

During the outbreaks, 40 growing-finishing crossbred castrated male pigs were submitted for necropsy in order to confirm the diagnosis of urolithiasis. Gross changes were 

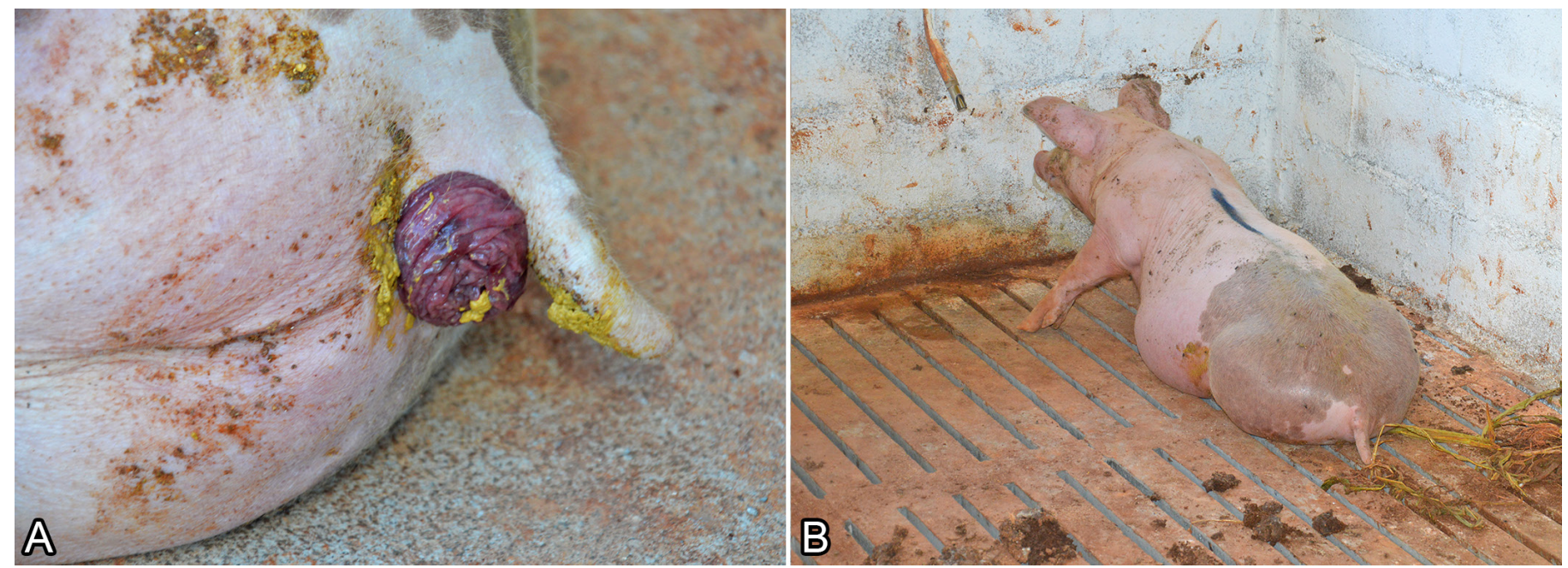

Fig.1. Obstructive urolithiasis in growing and finishing pigs. (A) Pig showing rectal prolapse. (B) Pig showing markedly distended abdomen and presenting persistent sternal decubitus position.
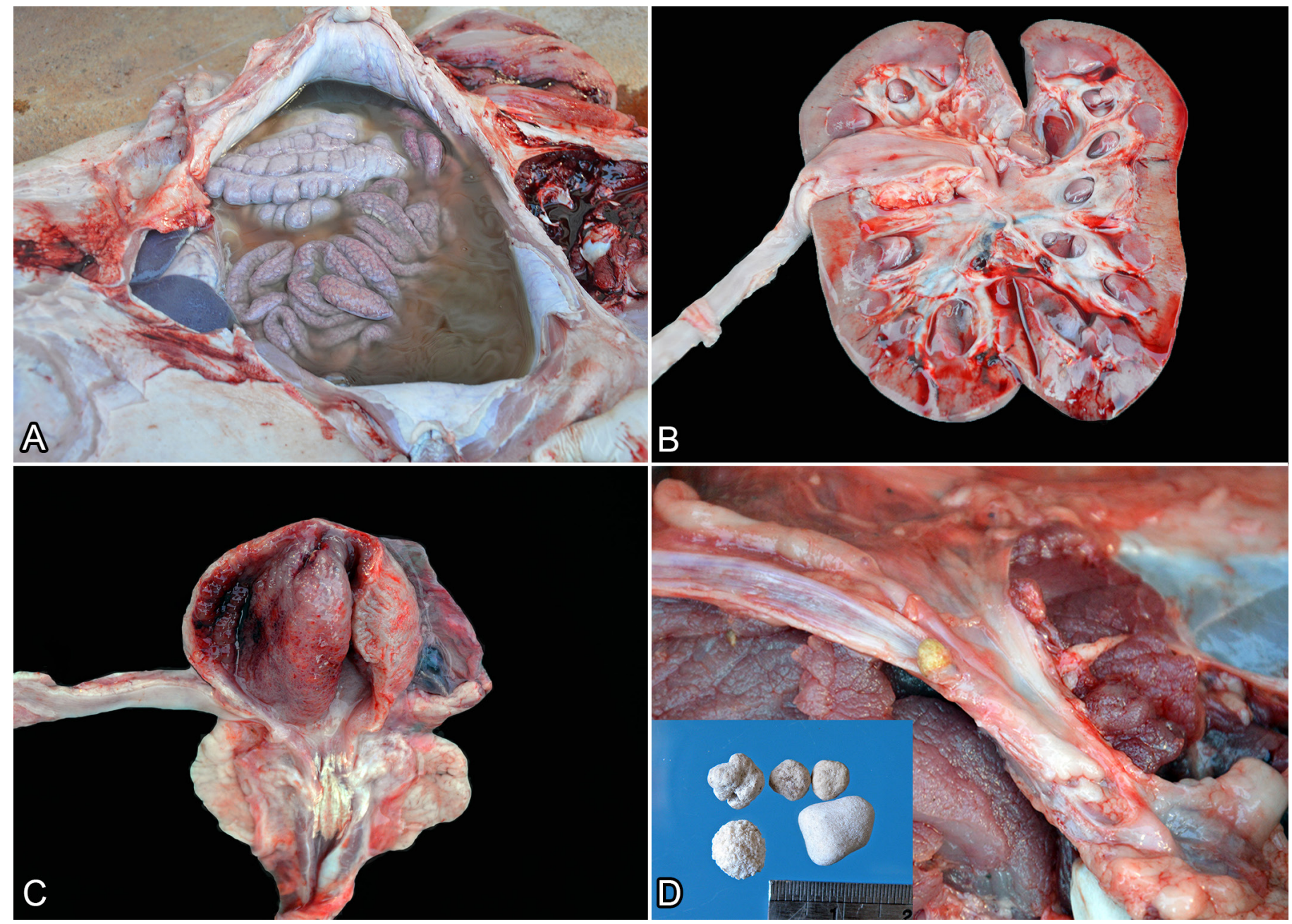

Fig.2. Obstructive urolithiasis in growing and finishing pigs. (A) Abundant amount of free yellowish fluid, presenting ammoniacal odor (urine) in the abdominal cavity due to urinary bladder rupture. (B) Marked dilatation of ureter (hydroureter), and moderate renal pelvis dilation (hydronephrosis). (C) Diffusely reddened, thickened, and irregular urinary bladder mucosa. In the urethra, a focally extensive area of fibrin deposition is noted. (D) Urethral luminal obstruction due to a $0.5 \mathrm{~cm}$ in diameter calculus. Inset (left): size of uroliths. 


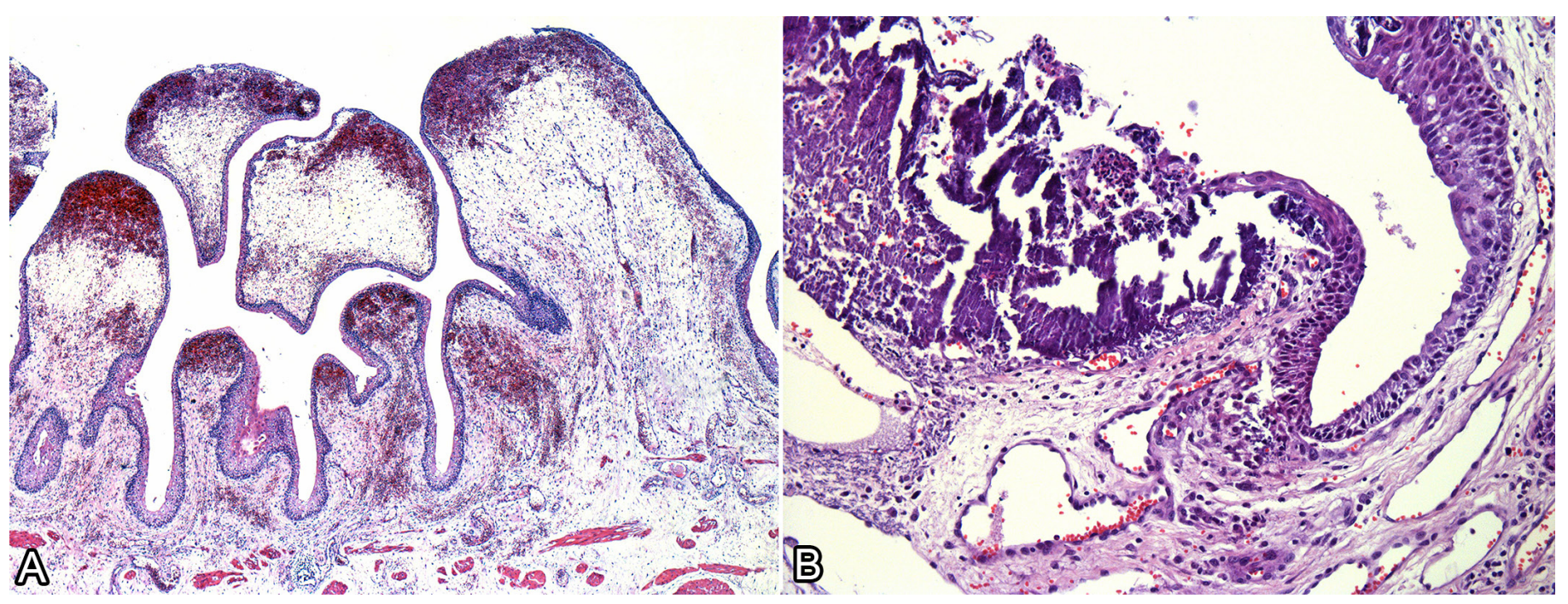

Fig.3. Obstructive urolithiasis in growing and finishing pigs. (A) Urinary bladder. Marked diffuse edema of the submucosa, associated with mucosal projections, as well as extensive areas of hemorrhage and multifocal inflammatory infiltrate. HE, obj.4x. (B) Urethra. Multifocal necrosis of the mucosal lining epithelium, associated with multifocal mild inflammatory infiltrate of neutrophils, lymphocytes and macrophages, as well as deposition of necrotic cell debris, foci of mineralization and bacillary basophilic bacterial aggregates. HE, obj.20x.'

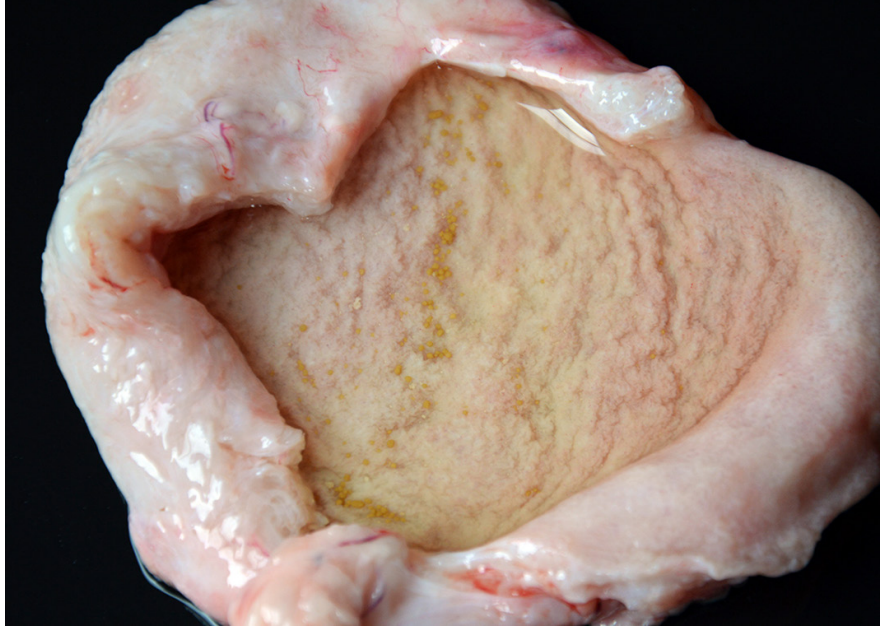

Fig.4. Obstructive urolithiasis in growing and finishing pigs. Urinary bladder presenting multiple uroliths ranging from 0.1 to $0.3 \mathrm{~cm}$ in diameter. Sample collected during slaughterhouse monitoring conducted in a group of swine with the previous history of urolithiasis.

characterized by bladder rupture associated with abundant amount of free yellowish fluid presenting ammoniacal odor (urine) in the abdominal cavity, as well as mild fibrin deposition on the surface of abdominal organs (Fig.2A), marked bilateral dilatation of ureters (hydroureter), and moderate renal pelvis dilatation (hydronephrosis) (Fig.2B). The urinary bladder mucosa was diffusely reddened, thickened, and irregular and presented mild yellowish fibrillar material (fibrin) deposition. In the distal urethral segment, a focally extensive area of fibrin deposition was noted (Fig.2C). Uroliths ranging from 0.3 to $1 \mathrm{~cm}$ in diameter were frequently observed obstructing the penile urethral lumen, and sometimes those were free in the abdominal cavity (Fig.2D). The urethral mucosa adjacent to the obstruction site was reddened and ulcerated.

Samples from four pigs were microscopically evaluated and showed diffuse marked edema in the urinary bladder submucosa, as well as extensive areas of hemorrhage and polypoid proliferation in the mucosa (Fig.3A). These lesions were associated with moderate inflammatory infiltrate of lymphocytes, plasma cells, and macrophages. In the penile urethra, marked multifocal necrosis of the mucosal lining epithelium, associated with deposition of necrotic cell debris, foci of mineralization, and bacillary basophilic bacterial aggregates were observed (Fig.3B). Mild to moderate fibrin deposition and infiltrate of neutrophils were noted in the peritoneum and in the serosa of the organs in the abdominal cavity. Marked mesothelial cell hypertrophy and mild fibrous connective tissue proliferation were evidenced in the serosa of the abdominal cavity organs, for instance, in the small and large intestine.

Ration samples of growing pigs (phases 1 and 2) showed magnesium, fluoride, sodium, and moisture levels within reference values recommended for the swine species. Nonetheless, the ration for growing pigs (phase 1) showed calcium and phosphorus values of $1589 \mathrm{mg} / \mathrm{Kg}$ and $4513 / \mathrm{Kg}$ respectively, which corresponds to a Ca:P ratio of approximately 0.35:1 (1.2:1). Ration for growing pigs (phase 2) presented calcium and phosphorus values of $4404 \mathrm{mg} / \mathrm{Kg}$ and $4169 \mathrm{mg} / \mathrm{Kg}$ respectively, representing a $\mathrm{Ca}: \mathrm{P}$ ratio of 1:0.95.

During the slaughterhouse monitoring, 20 urinary bladders were evaluated, of which only one presented uroliths (Fig.4). Six urine samples were submitted for analysis, and no significant alterations regarding density, $\mathrm{pH}$, cellularity, and presence of crystals were noted except for one sample, which presented a small amount of triple phosphate crystals (magnesium ammonium phosphate). 
Uroliths collected during the necropsy procedures were submitted to a mineral component qualitative test through the Cálculo Renal Bioclin ${ }^{\circledR}$ kit, which indicated that uroliths were composed of calcium carbonate and magnesium ammonium phosphate. Serum samples were collected from one of the pigs submitted for necropsy. Seric calcium and phosphorus levels were measured, revealing values of $7.05 \mathrm{mg} / \mathrm{dL}(7.1 \mathrm{mg} / \mathrm{dL})$ and $13.6 \mathrm{mg} / \mathrm{dL}(9.6 \mathrm{mg} / \mathrm{dL})$ respectively. After adjusting the dietary levels of calcium and phosphorus in the ration for growing-finishing pigs in the affected farms, clinical cases of obstructive urolithiasis were no longer observed.

\section{DISCUSSION}

The diagnosis of urolithiasis was based on the epidemiological, clinical, and pathological findings, along with the observation of uroliths in the urinary tract of affected animals. In the present study, obstructive urolithiasis was attributed to an imbalance in the ratio of calcium and phosphorus in the diet of growing pigs, since animals were fed the same ration, and the availability of drinking water in the facilities of affected farms was considered adequate in all outbreaks. Furthermore, after dietary levels of calcium and phosphorus in the ration for growing pigs were corrected in the affected farms, cases of obstructive urolithiasis were no longer reported.

Predisposing factors for the occurrence of urolithiasis include diet composition, mainly related to excess or imbalance of minerals, urinary $\mathrm{pH}$, reduced water intake, urinary stasis, metabolic disturbances, and preexistent urinary tract disease. Such predisposing factors may act synergistically or play a role individually in calculi formation (Drolet 2012, Sobestiansky 2012). Excessive consumption of minerals may be associated with artesian wells, and with unbalanced diets, which contain particularly high phosphate concentrations. Sheep fed on diets with high phosphorus concentration present hyperphosphatemia, and consequently show increased phosphorus urinary excretion, which may favor the precipitation of the excess of such mineral in the urinary tract (Radostits et al. 2000).

The ration fed to the growing pigs presented low calcium levels in its composition, which resulted in a calcium to phosphorus ratio of approximately $0.35: 1$, while the adequate proportion for the swine species is approximately 1.2:1; however, increased calcium proportions, ranging from 1.5 to 2.0, have also been recommended (Radostits et al. 2000, Moreno et al. 2012). Serum levels of calcium $(7.05 \mathrm{mg} / \mathrm{dL})$ were slightly below the recommended levels for the species, which is $7.1 \mathrm{mg} / \mathrm{dL}$, and seric levels of phosphorus (13.6/dL) were above the maximum reference values described for pigs, which is $9.6 \mathrm{mg} / \mathrm{dL}$ (Radostits et al. 2000, Jackson \& Cockcroft 2007).

Calcium carbonate uroliths are originated from calcium salts, which is the mineral type commonly found in pigs (Osborne et al. 1989, Maes et al. 2004), and horses (Neumann et al. 1994). However, differently from horses, which present large amounts of calcium carbonate crystals in the urine and frequently develop uroliths (Neumann et al. 1994), pigs rarely present spontaneous mineral precipitation (Maes et al. 2004). The formation of phosphate uroliths is directly related to the consumption of grain-based rations and mineral supplements, which lead to an increased excretion of phosphorus and magnesium through urine when compared with calcium. Increased levels of the referred minerals along with the availability of ammonia ions in the urine may act synergistically to promote calculogenesis (Manning \& Blaney 1986). Uric acid and urate uroliths are frequently observed in dehydrated neonatal piglets, and piglets presenting negative energetic balance, which results from an increase in the catabolism of tissue proteins and purines. Such calculi are observed as orange precipitated mineral deposits, which are noted in the kidneys, ureters, and in the urinary bladder (Kakino et al. 1998, Cianciolo \& Mohr 2016). Calculi originated from urinary tract infection are occasionally observed in sows (Drolet 2012). In these situations, crystalluria, characterized by abnormal microscopic precipitation, is considered an important risk factor for the development of urinary tract diseases, such as cystitis and pyelonephritis of bacterial origin (Carr et al. 1995, Drolet 2012, Chigerwe et al. 2013).

Although the occurrence of obstructive urolithiasis is considered to be sporadic, outbreaks affecting large numbers of animals have been reported (Manning \& Blaney 1986, Radostits et al. 2000). Pigs rarely develop urolithiasis comparatively with other animal species. Sporadic cases of urolithiasis have been described in pigs of all age groups and occasionally as an incidental finding in swine at the slaughterhouse (Drolet 2012). Even though urinary sediment is frequently observed in both male and female adult pigs, obstructive urolithiasis leading to death of affected pigs is a disease exclusively reported in castrated males. This condition is probably related to the great length and small diameter presented by the urethra in the referred swine category (Carr et al. 1995, Maes et al. 2004).

Typical clinical signs of urinary obstruction by uroliths include reduced feed intake, oliguria or anuria, and abdominal distention and pain (Drolet 2012) similar to the findings described in the reported outbreaks. Lethality rate was high in all studied farms, since all pigs presenting clinical signs of obstructive urolithiasis died. In these cases, death usually results primarily from urinary bladder rupture and secondarily from complete urethral obstruction by calculi, which leads to progressive urine leakage to the abdominal cavity, culminating in a markedly distended abdomen (Radostits et al. 2000, Loretti et al. 2003). Hypertonic urine associated with uroperitoneum promotes the leakage of large amounts of extracellular fluid to the abdominal cavity, leading to severe dehydration, abdominal distention, as well as cardiovascular alterations (Gasthuys et al. 1993, Loretti et al. 2003). Urethral or urinary bladder rupture usually takes place within 2 to 3 days, and death results from uremia or secondary bacterial infection (Radostits et al. 2000, Maes et al. 2004), however, none of the pigs from this study had uremic lesions.

The treatment of pigs with obstructive urolithiasis is mainly surgical (Larson 1996, Van Meter et al. 1996); however, it is not considered economically feasible (Drolet 2012). The main preventive measure for urolithiasis is the supplementation of calcium and phosphorus in the ratio of 2:1 respectively, 
in the complete diet (Radostits et al. 2000). Other measures include the addition of $4 \%$ sodium chloride in the diet, to stimulate water consumption and increase urine production (Radostits et al. 2000, Loretti et al. 2003), and to ensure that pigs raised in confinement facilities have access to adequate water supply and balanced diets, as well as to avoid urinary tract infections. After adjusting the dietary levels of calcium and phosphorus in the ration for growing-finishing pigs in the affected farms, clinical cases of obstructive urolithiasis were no longer observed.

\section{CONCLUSIONS}

In this study, the cause of obstructive urolithiasis was attributed to a nutritional imbalance in the ratio of calcium and phosphorus in the diet. The ration for growing animals fed to the affected pigs presented low calcium levels, which may have led to elevated phosphate excretion through the urinary tract. All affected animals were male and presented clinical signs of reduced feed intake, oliguria or anuria, abdominal distention and pain, with consequent death due to bladder rupture. Lethality rate reached $100 \%$.

Mineral components which predominated in the uroliths found in the present study were calcium carbonate and magnesium ammonium phosphate. The chemical composition of uroliths and environmental risk factors must be considered to determine adequate preventive measures for urolithiasis. It is also crucial to point out the importance of appropriate nutritional management practices to prevent the occurrence of such condition in swine production systems.

Acknowledgments.- The authors thank the Conselho Nacional de Desenvolvimento Científico e Tecnológico (CNPq), Process CNPq 406416/2016-8, and Coordenação de Aperfeiçoamento de Pessoal de Nível Superior (CAPES) for supporting this study. We would like to thank Fundação de Amparo à Pesquisa do Rio Grande do Sul (FAPERGS), Process 17/2551-000946-0 for the scholarship.

Conflict of interest statement.- The authors have no competing interests.

\section{REFERENCES}

Carr J., Walton J. \& Done S. 1995. Cystitis and ascending pyelonephritis in the sow. In practice 17(2):71-79. <http://dx.doi.org/10.1136/inpract.17.2.71>

Chigerwe M., Shiraki R., Olstad E.C., Angelos J.A., Ruby A.L. \& Westropp J.L. 2013. Mineral composition of urinary calculi from potbellied pigs with urolithiasis: 50 cases (1982-2012). J. Am. Vet. Med. Assoc. 243(3):389393. <http://dx.doi.org/10.2460/javma.243.3.389><PMid:23865881>

Cianciolo R.E. \& Mohr F.C. 2016. Urinary system, p.377-463. In: Maxie G. (Ed.), Jubb, Kennedy and Palmer's Pathology of Domestic Animals. Vol.2. 6th ed. Elsevier, Ontario. <http://dx.doi.org/10.1016/B978-0-70205318-4.00010-3>
Drolet R. 2012. Urinary system, p.363-380. In: Zimmerman J.J., Karriker L.A., Ramirez A., Schwartz K.J. \& Stevenson G.W. (Eds), Diseases of Swine. 10th ed. Wiley-Blackwell, Iowa.

Gasthuys F., Steenhaut M., De Moor A. \& Sercu K. 1993. Surgical treatment of urethral obstruction due to urolithiasis in male cattle: a review of 85 cases. Vet. Rec. 133(21):522-526. <http://dx.doi.org/10.1136/vr.133.21.522> <PMid:8310629>

Jackson P.G.G. \& Cockcroft P.D. 2007. Haematology and blood biochemistry in the pig, p.257-261. In: Ibid. (Eds), Handbook of Pig Medicine. Saunders Elsevier, Cambridge. <http://dx.doi.org/10.1016/B978-0-7020-28281.50021-9>

Kakino J., Sato R. \& Naito Y. 1998. Purine metabolism of uric acid urolithiasis induced in newborn piglets. J. Vet. Med. Sci. 60(2):203-206. <http://dx.doi. org/10.1292/jvms.60.203><PMid:9524944>

Larson B.L. 1996. Identifying, treating, and preventing bovine urolithiasis. Vet. Med. 91:366-377.

Loretti A.P., Oliveira L.O., Cruz C.E.F. \& Driemeier D. 2003. Clinical and pathological study of an outbreak of obstructive urolithiasis in feedlot cattle in Southern Brazil. Pesq. Vet. Bras. 23(2):61-64. <http://dx.doi. org/10.1590/S0100-736X2003000200003>

Maes D.G.D., Vrielinck J., Millet S., Janssens G.P.J. \& Deprez P. 2004. Urolithiasis in finishing pigs. Vet. J. 168(3):317-322. <http://dx.doi.org/10.1016/j. tvjl.2003.09.006><PMid:15501150>

Manning R.A. \& Blaney B.J. 1986. Epidemiological aspects of urolithiasis in domestic animals in Queensland. Aust. Vet. J. 63(12):423-424. <http:// dx.doi.org/10.1111/j.1751-0813.1986.tb15924.x><PMid:3800799>

McIntosh G.H. 1978. Urolithiasis in animals. Aust. Vet. J. 54(6):267-271. <http://dx.doi.org/10.1111/j.1751-0813.1978.tb02456.x><PMid:687293>

Moreno A.M., Sobestiansky J. \& Barcellos D. 2012. Deficiências nutricionais. p.615. In: Sobestiansky J. \& Barcellos D.E.S.N. (Eds), Doenças dos Suínos. $2^{\text {a }}$ ed. Cânone Editorial, Goiânia.

Neumann R., Ruby A., Ling G., Schiffman P. \& Johnson D. 1994. Ultrastructure and mineral composition of urinary calculi from horses. Am. J. Vet. Res. 55(10):1357-1367. <PMid:7998690>

Osborne C., Sanna J., Unger L., Clinton C. \& Davenport M. 1989. Analyzing the mineral composition of uroliths from dogs, cats, horses, cattle, sheep, goats and pigs. Vet. Med. 8:750-765.

Radostits O.M., Blood D.C., Gay C.C. \& Hinchcliff K.W. 2000. Clínica veterinária, p.441-445. In: Ibid. (Eds), Um Tratado de Doenças dos Bovinos, Ovinos, Suínos, Caprinos e Equinos. 9a ed. Guanabara Koogan, Rio de Janeiro.

Sobestiansky J. 2012. Condições diversas. In: Sobestiansky J. \& Barcellos D.E.S.N. (Eds), Doenças dos Suínos. 2 a ed. Cânone Editorial, Goiânia, G0. 835p.

Van Meter D.C., House J.K., Smith B.P., George L.W., Angelos S.M., Angelos J.A. \& Fecteau G. 1996. Obstructive urolithiasis in ruminants: medical treatment and urethral surgery. Compendium Cont. Educ. 18:317-328. 